Lucrările Seminarului Geografic Dimitrie Cantemir

Vol. 45, October 2017, pp. 191-200

http://dx.doi.org/10.15551/lsgdc.v45i0.16

\title{
The occupational structure of Mureş County in 2011
}

\author{
George-Bogdan Tofan' ${ }^{1}$, Adrian Niţă ${ }^{2}$ \\ ${ }^{1}$ Vasile Goldiş Western University of Arad, Romania \\ 2 Babeș-Bolyai University of Cluj-Napoca, Romania
}

To cite this article: Tofan, G.-B \& Niță, A. (2017). The occupational structure of Mureş County in 2011. Lucrările Seminarului Geografic Dimitrie Cantemir, Vol. 45, pp. 191-200. DOI:

10.15551/lsgdc.v45i0.16

To link to this article: http://dx.doi.org/10.15551/lsgdc.v45i0.16 


\title{
THE OCCUPATIONAL STRUCTURE OF MUREŞ COUNTY IN 2011
}

\author{
George-Bogdan Tofan', Adrian Niţă²
}

\begin{abstract}
This study intends to present several aspects concerning the occupational structure of the population inhabiting Mureş County and its 102 lower-tier administrative units, based on statistical data registered at the last census. From a total population of 550,846 people, $41.2 \%(226,925)$ are active, while $58.8 \%(323,921)$ are inactive. Within the active population, many are employed in the service sector, $42.4 \%$, followed by industry and constructions $31.2 \%$, agriculture with $23.7 \%$, and quaternary activities $2.7 \%$. Roughly $8 \%$ of the active population are unemployed. Within the inactive population, the highest share is held by pensioners $39.4 \%$, a category comprising other situations (other types of dependants) $26 \%$, students and pupils $25 \%$, and house workers, with $9.6 \%$. According to the occupational status, most are salarymen $(75.1 \%)$, followed by self-employed, $14.4 \%$, family workers (without pay), $8.9 \%$, owners/employers, $1.2 \%$, and members of agricultural societies/cooperatives and other situations, with $0.1 \%$ each.
\end{abstract}

Keywords: 2011 Census, active, inactive, economic sectors, social-economic dependance

\section{Introduction}

Widely known as occupational structure, this geodemographical category reflects the activities that take place in a certain area, registering, based on the social and economic evolution, significant changes from one period to another. For this reason, its quantification and analysis requires significant all-round effort.

We therefore distinguish two major population groups, one that performs paid and beneficial professional activities (V. Surd, 2001), also named active population, and another which does not have its own income, called inactive or dependant population (students, retirees, house workers, and other dependants).

Without going into much detail, we would like to point out the fact that, until today, there have been papers tackling this category from a broader perspective, focusing on some geographical areas that encompass the county, such as: Târnave Plateau (A. Maier \& J. Benedek, 1996), Mureş Plain (Emanuela Tănasă, 2007) and Mureş Defile (V. Mara, 2005; G. B. Tofan, 2014).

There is however one monographic paper, published by the Romanian Academy, which focuses exclusively on this county and contains a study of its occupational structure (I. Şoneriu, I., Mac, 1973). This study also influenced a series of later theoretical and methodological

\footnotetext{
1 „Vasile Goldiş” Western University of Arad, Faculty of Economic Sciences, Engineering and Informatics, Departament of Engineering and Informatics, Baia Mare Branch, 5 Culturii Street, Romania, e-mail: bogdan.tofan@uvvg.ro.

2 „Babeș-Bolyai” University, Faculty of Geography, Gheorgheni Branch, Csiki Garden, Romania, e-mail: nitaadrian@hotmail.com.
} 
papers (V. Surd \& L. Nicoară, 1990; Gr. P. Pop., 2000, 2012; N. Ciangă \& Ramona, Raţiu 2003; C. Vert, 2001).

\section{Methodology}

The territorial representation of the occupational structure of Mureş County in 2011 is based on the statistical data provided by the County Statistics Department, through its http://www.mures.insse.ro online platform, which facilitated the creation of comprehensive analyses. Therefore, we obtained data on employed population, according to national economy activities and occupational status. Then the statistical data was put into table, graphical and map formats, thus providing easy read and understanding of the issue at hand.

The current active population, for all 102 administrative units of the county, was divided into the four economic sectors, primary (agriculture, forestry, hunting, and fishing), secondary (industry and constructions) and tertiary (trade; vehicle repair; transport and storage; hotels and restaurants; financial and insurance brokerage; real estate; administrative services and support activities; local government and defence; public social insurance; education; healthcare; culture and entertainment; other services; private household activities). The last sector, quaternary, encompasses activities such as information technology and communications (ITC), professional, scientific and research activities, activities performed by NGOs.

The second population category, without income, is also known as inactive or dependant population. It comprises: pupils and students, retirees, house workers and others (dependant on other people, government or private organization dependant, other sources etc). Another aspect worthy of mention is that there have been difficulties in properly developing a territorial distribution of the population based on economic sectors, for the county's lower-tier administrative units. Marking with an * (asterisc) of the area where the number of people is lower than three determined a approximation of the corresponding values, which formed the basis of a cartographic representation of the four economic sectors.

\section{General occupational structure of Mureş County}

At the last census held in Romania (on 20th October 2011), the active population of Mureş County numbered 226,925 people (41.2\% of the 550,846 inhabitants). In 2002, the same population numbered 208,389 people or $35.8 \%$ of the entire population. This increase is due to the surge of population following Decree no. 779 regarding birth control (in effect starting 1st October 1966), as well as to a reduction in the young population and a constant older populace (around 39\%). This is also confirmed by the increase of the activity index from the 30-34 age group, in 2002, to the 40-44 group, in 2011. Following the gender structure of the active population, one might observe a strong male majority, in urban as well as in rural areas, $(55.2 \%)$ compared to females $(44.8 \%)$. Similarly to the national situation, this can be explained by a slightly higher female presence in three of the inactive populations (students, retirees, and house workers).

The inactive population decreased, from 48,541 in 2002 to 323,921 people in 2011 (58.8\% of the total county population). The decrease in birth rates in the last three decades caused a constant drop in the school age population, which led to accelerated population aging. 
In terms of gender, the inactive female population is more numerous $(55.7 \%)$, due to a slightly higher number of female graduates in the service sector and a lower life expectancy for men.

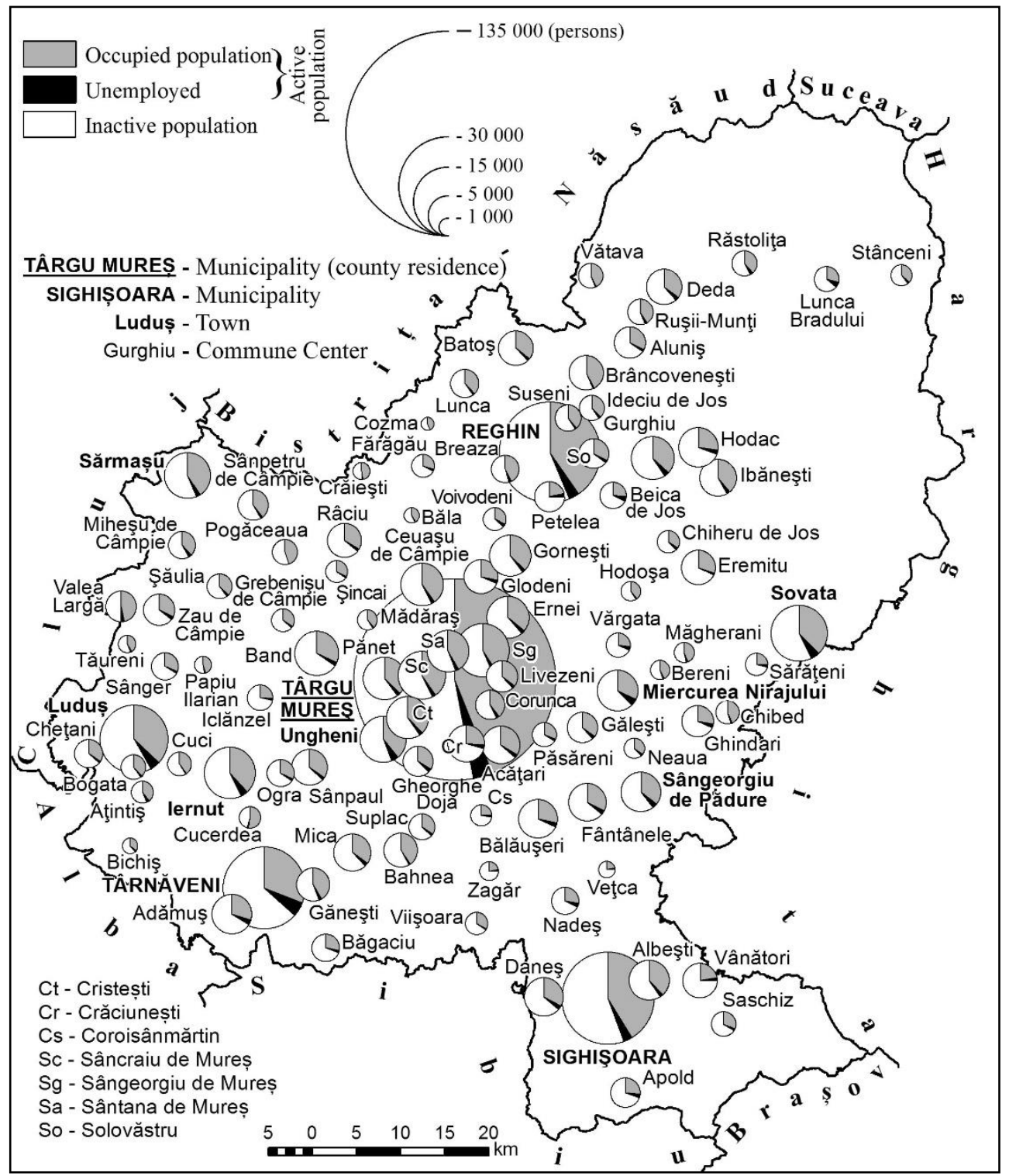

Figure 1: The percentages of active and inactive populations in Mureș County. Share of unemployed from the active population.

\subsection{The currently active population (major occupational groups)}

Out of the total working population ( $92.0 \%$ of the active population, meaning 208,841 people), most are employed in the tertiary sector, $42.4 \%$ (88,716 people), then in the secondary sector, $31.2 \%(65,194$ people), while $23.7 \%$ work in the primary sector $(49,488)$, and only 
$2.7 \%(5,443)$ in the quaternary sector. $8 \%$ of the active population is unemployed $(18,084$ people), out of which $31.6 \%$ (5,724 people) are looking for a place of work.

The occupational groups have major differences as well when we compare urban with rural areas, Thus, in urban zones, agricultural workers only make up 5.5\% (6,229 people) of the currently working populace 112,858 (91.7\%) of the urban active population), $36.7 \%$ work in industry and constructions (41,414 people), the majority $55.8 \%$ - being employed in the service industry $(62,997$ people), while only $3.8 \%$ (4,337 people) in the quaternary sector.

In rural areas, out of the total working population (95,983 people, $92.3 \%$ of the active population), in the same sector order, the values are as follows: $45 \%(43,259), 24.7 \%(23,780)$, $29 \%(27,838)$ and $1.1 \%(1,106)$. Out of the total 18,084 unemployed, 10,143 live in urban areas $(8.2 \%)$, while the remaining 7,941 (7.6\%) in rural areas. In the latter areas, the percentage of people who are looking for their first place of work is slightly higher $(32.6 \%)$.

a) The currently working population in the primary sector represents $23.7 \%(49,488$ people) of the total working population 208,841 people, and is employed in different activities involving agriculture, forestry, and fishing. Favourable orographic conditions, good climate and soils created the basis for a complex array of agricultural activities, both in terms of plant cultivation (grain, industrial plants and fodder, vegetables), and animal husbandry. Large tracts of farmland partially created the conditions for more than half of the county's administrative units to register more than 50\% agricultural workers.

For instance, the communes located in Mureş Plain (Transilvania Plain) register values above $70 \%$ in agricultural workers: Băla, Fărăgău, Papiu Ilarian, Pogăceaua, Sânpetru de Câmpie, Şăulia. The communes of Hodoşa and Bichiş, situated in Târnava Mica Hills (Târnave Plateau), have the highest values, the latter reaching $85.3 \%$. The only agricultural town in the Transilvania Plain, Sărmaşu (urban settlement since 2003), hasd an active agricultural population of $40.5 \%$. The presence of grain and fodder plantations also boosted animal husbandry, mostly pigs and poultry, in: Band, Iernut, Gorneşti, Râciu, and Luduş, while pastures and hayfields, mostly located in the north-eastern part of the county, allowed for the development of sheep and cattle raising, with extensive pendulating sheepherding in the Căliman and Gurghiu Mountains. A part of the population is employed in fruit-growing with large orchards (mostly apple trees) on the outskirts of the City of Reghin and Batoş Commune, and in forestry and logging operations in Mureş Gorge and Gurghiu Valley.

The existence of water bodies (lakes, ponds), many on the Pârâul de Câmpie (Transilvania Plain), created a population segment working in fish farming (carp), especially in Miheşu de Câmpie, Şăulia, Zau de Câmpie, Tăureni, Sânger etc.

b) Population currently working in the secondary sector also decreased at national level from the 1990s onwards, due to the closure of several industrial plants and the development of the service industry (especially trade). Consequently, the share of industry and construction workers decreased from $41.4 \%$ in 2002 to $31.2 \%$ in 2011 (65,194 people), influencing the urban active population, as well as the commuting rural population. $79.4 \%$ worked in industry while $20.6 \%$ in constructions. The most important natural resource, methane gas, led to population concentrations in activities involving construction materials (ceramics), energy industry and chemical industry (fertilizers, medicine and pharmaceutics), located in the larger towns and cities: Sighişoara (47.3\% the largest share), Iernut and Luduş with 39.7\% each, Târnăveni (38.8\%) and Târgu-Mureș (30.4\%).

The existence of large mountain woodlands enabled the development of logging industries, especially in Târgu-Mureş, Reghin, Sovata, Sângeorgiu de Pădure etc. The most 
developed industry however is still the light industry, with its two main branches, textiles and footwear-leather industry. The food industry employs two thirds of the active population, with bread making, meat packing, dairy and sugar, beer, soda and mineral water.

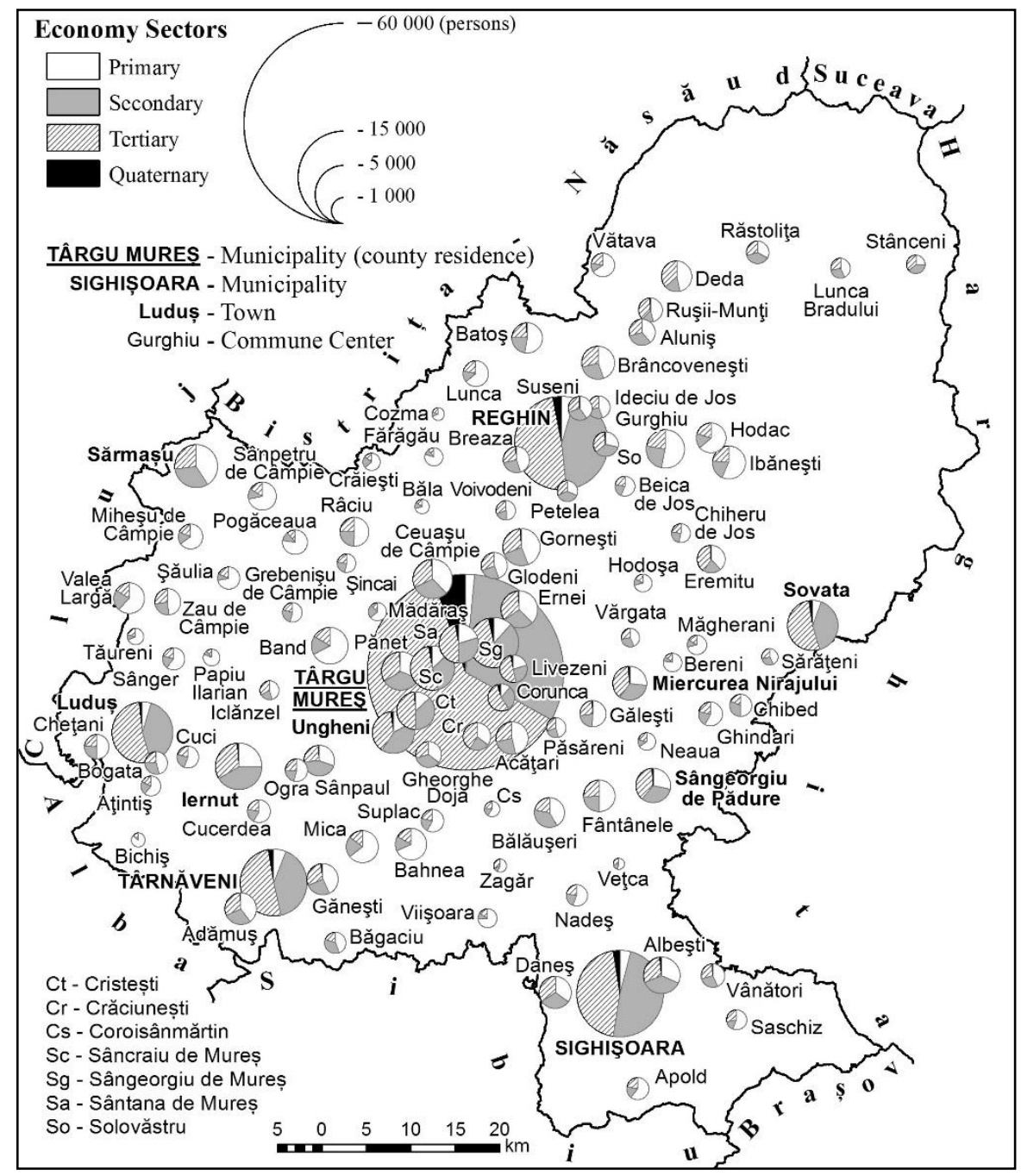

Figure 2: The working population of Mureș County (major occupational groups).

c) The population currently employed in the tertiary sector was the only category which registered an ascending trend, in 2011 having the largest share $42.4 \%$ of the working population $(88,716$ people). The category contains the following activities: trade, vehicle repair $(29.5 \%$ of the tertiary population); healthcare $(14.2 \%)$; education $(12 \%)$; public administration and defence, public social insurance $(11.7 \%)$; transport and storage $(9.8 \%)$; other service activities (7\%); hotels and restaurants $(4.8 \%)$; administrative services and support services $(4.4 \%)$; financial and insurance brokerage $(2.7 \%)$; activities in private households - production and services for own consumption $(1.7 \%)$; entertainment an cultural 
activities $(1.5 \%)$; real estate $(0.2 \%)$. The largest tertiary populations are in urban centres, where the primary and secondary populations register low values.

The most representative area for the tertiary population is Târgu-Mureş, with $61.6 \%$ of the total working population, due to its high number of individuals working in trade, healthcare, local government, education, and transport.

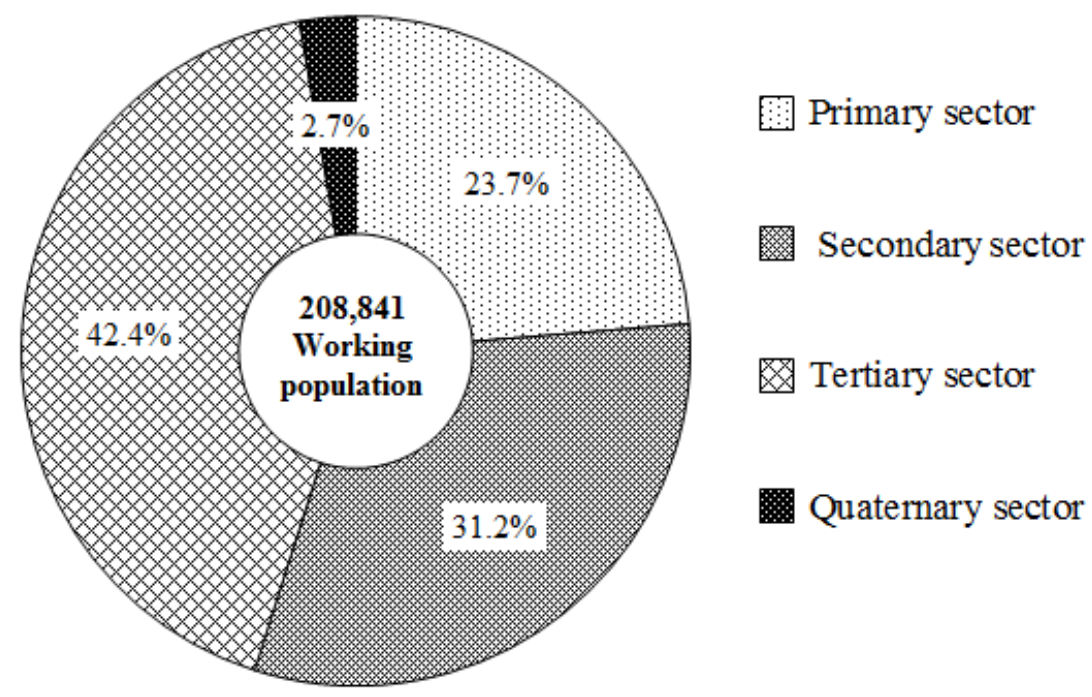

Figure 3: Share of the population working in each economic sector, Mureş County, 2011.

d) The population currently employed in the quaternary sector has a share of just $2.7 \%(5,443$ people) of the working population, with $48.4 \%$ in research (professional, scientific, and technical activities), $48.1 \%$ in ITC and $3.3 \%$ in NGOs. As expected the largest share of quaternary workers is found in Târgu-Mureş (5.3\%), an important university and research center, especially for medical and pharmaceutical activities.

\subsection{The inactive population}

At the 2011 Census, Mureş County registered an inactive population of 323,921 people, representing $58.8 \%$ of the 550,846 inhabitants of the county. Pensioners have a share of $39.4 \%$ (127,619 people), followed by pupils and students, with $25 \%$ ( 81,037 people), dependant on other persons, $15.6 \%(50,697)$, house workers, $9.6 \%(31,304)$, other situations with $6 \%$ $(19,656$ people), dependants on state and private organizations, $2.2 \%,(7,259)$ and dependants on other sources, $2 \%(6,349$ people).

a) Pupils and students register 81,037 people, representing a quarter of the total 323,921 inactive people. Compared to the 2002 census, there has been a dramatic decrease in their number, by 13,062 people, due to low birth rates, emigration, school abandonment etc..

The high values registered in the City of Târgu-Mureş are induced by the existence of renowned trade schools (pedagogical, medical, tehnical, economic) and a medical and pharmaceutical university. 
b) Pensioners register the highest share $(127,619$ people or $39.4 \%)$ of the total inactive population. Most elderly people from rural areas do not benefit from pensions, as their status is defined as unpaid family workers or other. Their income is composed of different indemnities and compensations, mostly for agriculture.

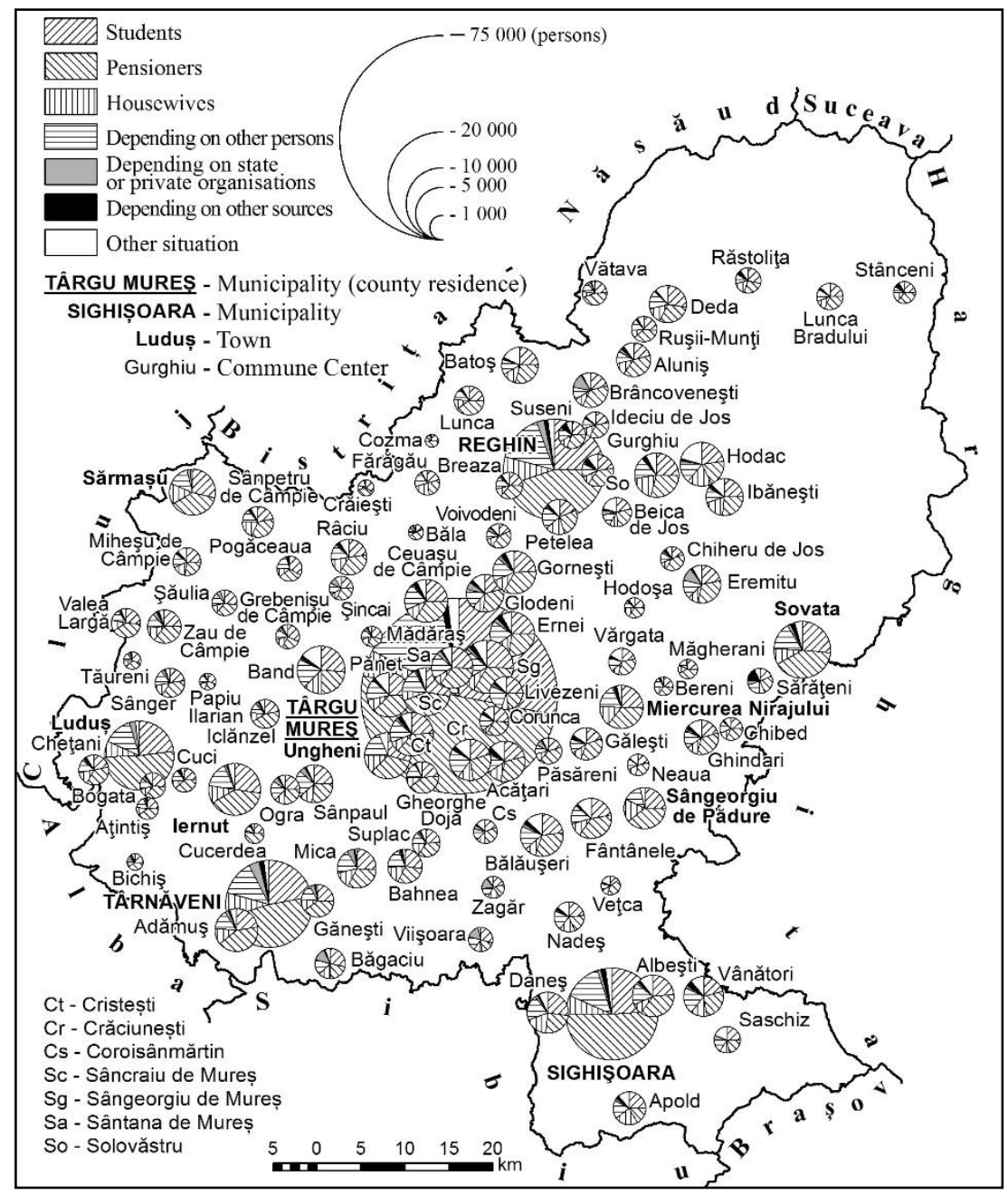

Figure 4: The inactive population of Mureș County (population categories).

Although pensions form the basic income for this category of people, it proves to be insufficient for agricultural pensioners, the lack of other paid activities being motivated by age and poor health.

c) Housewives (people with no occupation) represent $9.6 \%$ (31,304 people) of the total inactive population. Most are women, many with a low education level, whose inactivity is justified by the need to raise their children and perform house work. Many house wives are young (25-34 years of age) and of Gypsy ethnicity, due to their poor involvement in the labour market. 
d) The „other situations” category includes preschool children and school age children below 14, not enrolled in any type of education, but who perform house chores, the elderly, people with disabilities (for which the state pays a salary or maintenance to those who take care of them), dependant on people or public institutions (nursing homes, hospitals, foster homes etc) or on private organizations (NGOs). It also includes people whose income derives from rents, interests, dividends, bonds etc. In Mureş County, this category has significant share of the inactive population, roughly $26 \%$ (83,961 people), most found in rural areas.

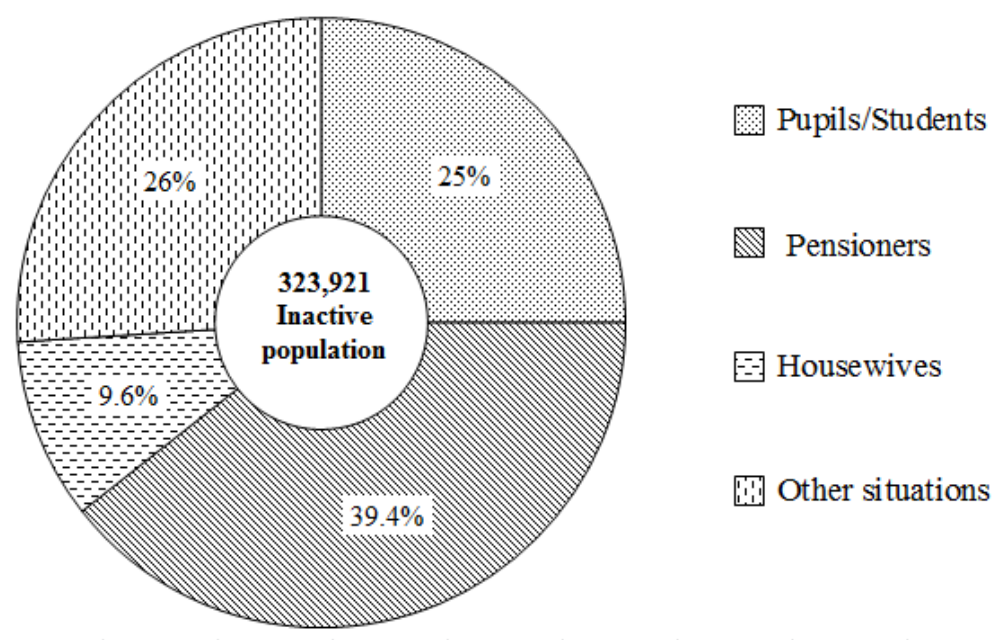

Figure 5: Shares of the inactive population categories in Mureş County, 2011.

\section{Conclusions}

In 2011 , out of the total county population, $41.2 \%$ were active, the highest share having been recorded in Târgu-Mureş (47\%), while the lowest in Zagăr (24.5\%) due to low birth rates and demographic aging. In terms of economic sectors, between 2002 and 2011, the number of agricultural and industry-construction workers dropped, while service and quaternary workers increased significantly (mostly in urban areas).

Taking into account the specificity of the selected theme, the best indicator for the occupational structure is the demographic dependance index, which registered a value of 643 dependants / 1,000 able-bodied individuals in 2011. In urban areas, this index is lower (574), while in rural areas it is above the county average (720), reflecting the demographic aging of the rural populace (especially in the Transilvania Plain) on one hand and the rather limited economic development of the county on the other.

The primary sector population (49,488 people) has a $23.7 \%$ share of the active population, with the highest value in Bichiş commune (85.3\%), while the lowest in TârguMureş (1.4\%).

Higher shares are recorded in the communes of the Mureş Plain and in the western half of the Târnava Mica Hills, with large farmlands, cultivated with grain (wheat, corn, barley), sugar beet, alfa-alfa, and clover, as well as potatoes and vegetables in smaller areas (Gr. P. Pop, 2012). 


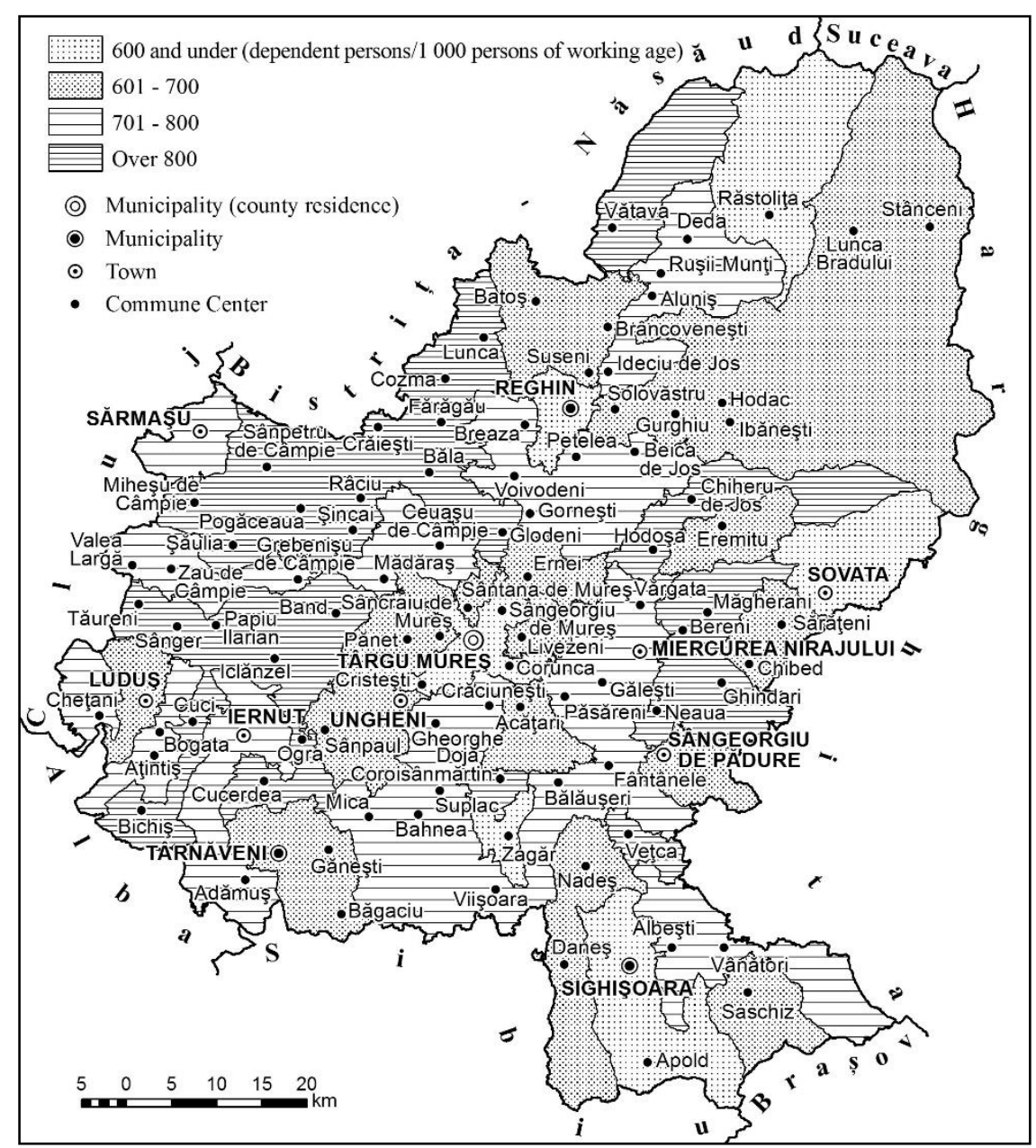

Figure 6: Mureș County. Demographic dependance index

The secondary sector population numbers 65,194 people, or $31.2 \%$ of the working population. The largest share was recorded in Sighişoara (47.3\%), due to a strong light and construction industry, while the lowest in Bichiş commune $(2.4 \%)$ due to an overwhelming part of the population (over $80 \%$ ) working in agriculture.

The tertiary sector population, with a share of $42.4 \%$ of the working population, had its highest recorded value in the county capital, where service workers reached $61.6 \%$ of the city's active population, situation determined by a trade dominance $(18.6 \%)$, followed by healthcare $(10.5 \%)$, public administration and social security $(8 \%)$, education $(7.1 \%)$, transport and storage.

The last sector had a small share of $2.7 \%$ of the county's working population. Most workers are concentrated in the City of Târgu-Mureş, while rural areas have a extremely minute share. People searching for a place of employment (unemployed), numbering 18,084 people ( $8 \%$ of the active population), were mostly found in Târnăveni $(15.6 \%)$, due to the closure of the chemical plant and the brick-ceramics factory, which employed most of the city's working population. 
The inactive population ( $58.8 \%$ at county level) was characterised by decreases in the number of students, retirees, and house workers, while the category comprising ,other situations" (dependants) grew.

Students have a $25 \%$ share of the active population, the City of Târgu-Mureş having the highest value (27.8\%), proportional to its demographic size, as well as due to the existence of several higher education institutions. The lowest share was found in Veţca (15.7\%), caused by very low birth rates and emmigration.

Retirees, with $39.4 \%$ of the inactive population, had the highest share in Ludus $(51.2 \%)$, and the lowest in Apold (16.5\%), with a high concentration of Gypsy ethnics (23\%) who have no state pensions.

House workers have a $9.6 \%$ share of the total inactives, the highest having been found in Apold, 23.2\% (mostly young Gypsy women), and the lowest in a commune on the Mureş River, Cucerdea, cu $3.3 \%$.

The ,other situations" category, $26 \%$ of the 323,921 inactive individuals in the county, has the highest share in Sărăţeni (48.8\%), where the inactive population depends on different types of welfare or agricultural allowance, and the lowest in Târgu-Mureş (18\%), with a much developed economy and a pensioner-based inactive population.

\section{References}

1. Ciangă N., Raţiu R. 2003. Geografia Umană a României. Îndrumător de lucrări practice, Edit. Dimitrie Contemir, Târgu Mureş.

2. Maier A., Benedek J. 1996. Aspecte privind structurile geodemografice în ruralul din Podişul Târnavelor, Studia UBB, Geographia, XLI, 1-2, Cluj-Napoca.

3. Mara V. 2005. Evoluţia populaţiei din Defileul Topliţa-Deda, vol. „Repere ale afacerilor în comerţ, turism şi servicii”, Centrul de Dezvoltare a Afacerilor în Turism, Comerţ şi Servicii, Edit. „Dimitrie Cantemir”, Târgu-Mureş.

4. Pop P. Gr. 2000. Funç̧iile şi dimensiunile urbanului din România, Studia UBB, Geographia, XLV, 1, Cluj-Napoca.

5. Pop P. Gr. 2012. Depresiunea Transilvaniei, Edit. Presa Universitară Clujeană, Cluj-Napoca.

6. Şoneriu I., Mac I. 1973. Județul Mureș, Edit. Academiei R.S. R, București.

7. Surd V., Nicoară L. 1990. The Socioprofessional Structure of the Active Population of the Rural Settlements in ,Ţara Oaşului”, Studia UBB, Geographia, XXXV, 1, Cluj-Napoca.

8. Surd V. 2001. Geodemografie, Edit. Presa Universitară Clujeană, Cluj-Napoca.

9. Tănasă E. 2007. Populaţia şi aşezările din Câmpia Mureşană (Câmpia Transilvaniei), Teză de doctorat, Universitatea „Babeş-Bolyai” Cluj-Napoca, Facultatea de Geografie, Cluj-Napoca.

10. Tofan, G. B. 2014. Defileul Mureşului. Studiu de Geografie Umană, Edit. Presa Universitară Clujeană, Cluj-Napoca.

11. Tofan G. B. 2014. Geodemographic characteristics of Mureş Defile, Studia UBB, Geographia, LIX, 2, Cluj-Napoca.

12. Vert C. 2001. Geografia populaţiei. Teorie şi metodologie, Edit. Mirton, Timişoara.

13. *** 2012. Reactualizarea Planului de amenajare a teritoriului judeţean, judeţul Mureş, partea I, Analiza situaţiei existente, vol. IV, Structura socio-demografică, Populaţia şi potenţialul demografic, proiectant: Universitatea „Babeş-Bolyai” Cluj-Napoca, Facultatea de Geografie, ClujNapoca.

14. http://www.mures.insse.ro, accesed: 24 th February 2017. 